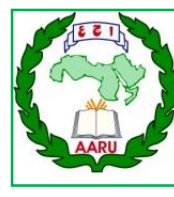

Arab Univ. J. Agric. Sci., Ain Shams Univ., Cairo, Egypt

29(2), 795-800, 2021

Website: http://ajs.journals.ekb.eg

DOI: 10.21608/ajs.2021.52876.1308

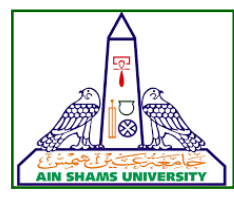

795

\title{
Impact of Saccharomyces Cerevisiae Boulardii Supplementation as Probiotic on Productive Performance and Economic Efficiency of Growing Rabbits
}

$[56]$

\author{
Basma MA El-Sawy ${ }^{*}$, Ayman MH Ahmed ${ }^{1}$, Yasser K Badawi², \\ Ibraheim H El-Wardany ${ }^{1}$
}

1-Poult Prod Dept, Faculty of Agric., Ain Shams University, P.O. Box 68, Hadayek Shoubra 11241, Cairo, Egypt

2- Animal Prod Res Instit, Agricultural Res Center, Minist of Agric Dokki, Giza, Egypt

*Corresponding author: elsawy1966@Gmail.com

Received 8 February, 2021

Accepted 24 May, 2021

\begin{abstract}
Our study was carried out at the farm of Faculty of Agriculture, Ain Shams University, Egypt. The average temperatures were $18.4^{\circ} \mathrm{C}$ and $23.9^{\circ} \mathrm{C}$ from December 2017 - February 2018 to study the effects of Saccharomyces cerevisiae boulardii supplementation (as feed additives) on productive performance of growing rabbits. Sixty growing rabbits of the NZW (New Zealand White Rabbits), (4 weeks old) and weighted (603.62 gm mean body weight) were randomly distributed into 4 treated groups, $n=15$ rabbits per each group. Rabbits of supplemented groups were given 100 (R1), 200 (R2) and 400 (R3) gm/ton feed of Saccharomyces cerevisiae boulardii mixed in the diet for 6 successive weeks. Individual live body weight was noted weekly from start till the end of the experiment. At the end of the experimental period, 10 rabbits (from each group) were fasting for $12 \mathrm{hrs}$, then slaughtered for carcass traits measure. Experimental lighting system was 16-hours photoperiod /day (16L: 8D) through both daily natural and the artificial fluorescent lighting. A pelleted ration of $17.3 \%$ crude protein, $13.37 \%$ crude fiber and $2510 \mathrm{kcal}$ of digestible energy per $\mathrm{kg}$ feed was offered ad libitum all the time. Results re-
\end{abstract}

vealed significant $(\mathrm{P} \leq 0.05)$ increases in the final body weight and daily weight gain with saccharomyces cerevisiae supplementation when compared with control group. Though, significantly $(\mathrm{P} \leq 0.05)$ improved feed conversion ratio in all treated groups compared with control one were noticed. Feed intake was the lower in treated groups than control group. There were significant $(\mathrm{P} \leq 0.05)$ increasing in hot carcass weight and carcass percentage with respect to the control group. Supplemented Saccharomyces cerevisiae reduced $(\mathrm{P} \leq 0.05)$ the liver, heart, lungs and kidneys percentages compared the control group. Supplemented rabbit feeds with saccharomyces cerevisiae boulardii in their diets had highly increasing in relative economic efficiency and clear improvement of net revenue than control group.

Keywords: Saccharomyces cerevisiae, additive, carcass, economic, rabbits.

\section{Introduction}

Insufficient quantity of animal protein source is a main problem in developing nations including Egypt. Rabbits are suitable sources of palatable and beneficial meat, little fats and cholesterol concentrations, therefore its appro- 
priateness as special diet (Owen 1981). Rabbits are simple stomach herbivores. Its digestive structure is suitable for high fiber contents like cellulose in the diet. Several studies were reported that elevated cellulose diets are advantageous for depressing death rates by the mechanism of their appendix vigor which motivates their ileum.

Inclusion of living yeast in animal diet has been shown to impact the digestibility, nutritive efficiency of feed utilization, and production of experimental animals. Bio-active yeast elevates digestibility and nutritive efficiency of feed utilization through secretes enzymes (Ozcan 2001). Basavaraj et al (2011) stated that rabbits might be able to convert $20 \%$ of the proteins in diets which they consume into edible meat whereas beef could be converted only $8-12 \%$.

It is well acknowledged that feed additives could be used safely in rabbit's ration to improve their production. Feed additives additional to diets in very minor quantities with the objective of obtaining some different effect. The mechanism of probiotics has not been well clarified, but it might include: (1) encouragement of enzyme created by the host, (2) decrease of toxin production, (3) competitions for adhesion to epithelial cells and augmented resistance to colonization, (4) manufacture of some vitamins or antimicrobial constituents, (5) encouragement of the immune system of the host and finally (6) decline of stress of rabbits (Falcao-e-Cunha et al 2007, Shehata and Tawfeek 2010).

Medical antibiotics are still commonly used to decrease mortality rates in rising rabbits, while there are development concems over medicine residues in meat foodstuffs and rises in resistance of bacteria due to the prophylactic use of these antibiotics. As a result of this, the usage of replacements of antibiotics has received reintroduced emphasis (Bovera et al 2012a). Yeast in diets has been recognized as a probiotic in animal's feed (Saegusa et al 2004). In rabbits, supplementation of live yeast as feed additives provided some progressive effects on growth performance and fitness status (Maertens and De Groote 1992). These positive effects vary depending on its dose in diet, rabbit`s age, livestock experimental conditions.

Onifade (1998) reported that supplementation of yeast on animal feeds due to yield numerous advantageous impacts. Though, the mode of action of live yeast for optimizing performance is not fully understood, but may be there are two probabilistic explanations. Firstly, action of yeast is most probably supportive the development of lactic acid bacteria. Secondly, a competitive rejection of pathogenic bacteria by yeast and its produces mainly the cell wall component (Onifade 1998). Cell wall of yeast is containing chitin, glucan and mannan which have been identified as immunostimulante (Li and Gatlin 2003). This study aimed to explore the effects of Saccharomyces cerevisiae supplement on the growth performance, carcass traits and economic efficiency of growing rabbits.

\section{Materials and Methods}

Experiment was carried out at the rabbit's farm of Faculty of Agriculture, Ain Shams University, Kaluobia governorate, Egypt. The average temperatures of the area vary between $18.4^{\circ} \mathrm{C}$ and $23.9^{\circ} \mathrm{C}$ within the experimental period from December 2017 - February 2018 to study the effect of Saccharomyces cerevisiae boulardii as feed additives on productive performance of growing rabbits (Oryctolagus cuniculus). Sixty New Zealand White rabbits (NZW), (4 weeks old) and approximately (603.62 gm mean body weight) were randomly and equally distributed into four groups $(n=15$ rabbits per group). The animals were kept in individual commercial cages $(40 \times 35 \times 30 \mathrm{~cm}$, $0.14 \mathrm{~m} 2$ ) supported with drinking nipple and feeding hopper (35 $\mathrm{cm}$ available) each one. Lighting regime was (16L: 8D) 16-hours light /day through both natural photoperiod and fluorescent lighting. The basal diet was formulated to meet the recommended nutrient requirements of growing rabbits according to De Blas and Mateos (1998). They were allowed to a standard pellet diet $(17.3 \%$ crude protein, $13.37 \%$ crude fiber and $2510 \mathrm{Kcal} / \mathrm{kg}$-ration 
DE). Feed and water were available ad libitum. The diet was exposed to chemical analysis according to AOAC (1999). Clean and fresh water were straightly available at all periods during the study which lasted for 6 weeks. Weekly live body weight was individually recorded at the experimental day one till the end of the experimental period. Finally, at the end of 10 weeks, 10 rabbits (from each group) were slaughtered for carcass traits.

Experimental design:

Group1: Basal diet as a control group (C).

Group2: Add 100 gm Saccharomyces cerevisiae */ton diet (R1).

Group 3: Add 200 gm Saccharomyces cerevisiae / ton diet (R2).

Group 4: Add 400 gm Saccharomyces cerevisiae / ton diet (R3).

Diet additives: * = Saccharomyces cerevisiae was provided as Lallamend ${ }^{\circledR}$-(Levucell strains)

Initial and final live body weight (IBW and FBW), feed intake (FI) was recorded weekly and (BWG) body weight gain, (FCR) feed conversion ratio were considered. At the end of the experimental, carcass characteristics were evaluated for 10 rabbits from each treatment. Finally, economic efficiency was determined. All data were exposed to analysis of variance according to the statistical analysis system (SAS 2002). The differences among groups means were Duncan's multiple rang test (Duncan 1955).

\section{Results and Discussion}

\subsection{Growth performance}

Data in Table 1 presented significant $(\mathrm{P} \leq 0.05)$ increases in daily body weight gain, final body weight, relative growth rate and significantly $(\mathrm{P} \leq 0.05)$ improved feed conversion ratio in treating individuals compared with control ones. Rabbits in group R3 recorded the heavier final body weight, highest daily weight gain, highest growth rate and best feed conversion ratio at the end of experiment. Also, treated groups were the lower feed intake. The mortality rate was not affected by treatment. The use of some organic substances, possessed to improve the growth performance of animals, through enhancing feed efficiency and immune response. One of these substances is yeast (Saccharomyces cerevisiae). Saccharomyces cerevisiae have considered as a good source of probiotic and prebiotic organisms which could conserve rabbit growth rate characteristics, and likewise related with vital promoting effects. Results are in agreement with Nilay and Nurten (2014) who reported that supplementation of Saccharomyces cerevisiae to rabbit diet led to improving in LBW and BWG. In addition, Chuka and Didacus (2010) reported that rabbits fed diets supplemented with Saccharomyces cerevisiae had significant $(\mathrm{P} \leq 0.05)$ higher values of BWG, feed utilization and FCR. Amber et al (2014) found that the addition of probiotic and prebiotic to rabbit diet had significantly improved $(\mathrm{P} \leq 0.01)$ in final experimental animal weight, weight gain and relative growth rate. Kritas et al (2008) found that administration of the commercial probiotic BioPlus significantly improves average body weight and daily weight gain. Moreover, Toghyani et al (2011) stated that diet addition of probiotic $\left(15 \mathrm{mg} / \mathrm{kg}\right.$ Protoxin $\left.^{\mathrm{TM}}\right)$ and prebiotic (1g/kg mannanoligosaccharide) statistically increased $(\mathrm{P}<0.05)$ broiler body weight at 28 and 42 days of age when compared with to the control chicks. Shrivastava et al (2012) who reported that adding yeast to growing rabbit feeds significantly improving finishing body weight, daily body weight gain and FCR.

On the other hand, Belhassen et al (2016) found no effects of yeast addition on growth traits, composition of caecal microbiota, slaughter traits were found.

\subsection{Carcass traits}

Supplementation with Saccharomyces cerevisiae continiously after weaning till 70 days of age increased significantly $(\mathrm{P} \leq 0.05)$ hot carcass weight and carcass\% in respect to the control group (Table 2). While, there was an improvement in dressing\% with supplementation of Saccharomyces cerevisiae but the differences were not significant. Supplemented Saccharomyces cerevisiae reduced 
Table 1. Effect of feeding different levels of Saccharomyces cerevisiae on productive performance of growing rabbits at 70 days of age

\begin{tabular}{|c|c|c|c|c|c|}
\hline \multirow{2}{*}{ Body weight at: } & \multicolumn{4}{|c|}{ Body weight (g) } & \multirow{2}{*}{ S.E. } \\
\cline { 2 - 5 } & $\mathbf{C}$ & $\mathbf{R 1}$ & $\mathbf{R 2}$ & R3 $^{*}$ & \\
\hline Initial body weight, g & $598.95^{\mathrm{a}}$ & $609.50^{\mathrm{a}}$ & $600.00^{\mathrm{a}}$ & $606.04^{\mathrm{a}}$ & 15.96 \\
\hline Final body weight, g & $1671.00^{\mathrm{b}}$ & $1776.87^{\mathrm{b}}$ & $1751.62^{\mathrm{b}}$ & $1998.41^{\mathrm{a}}$ & 37.80 \\
\hline Daily weight gain, g & $25.53^{\mathrm{c}}$ & $27.79^{\mathrm{b}}$ & $27.42^{\mathrm{b}}$ & $33.15^{\mathrm{a}}$ & 3.49 \\
\hline Relative growth rate & $93.88^{\mathrm{b}}$ & $97.53^{\mathrm{b}}$ & $97.17^{\mathrm{b}}$ & $105.72^{\mathrm{a}}$ & 2.29 \\
\hline Daily feed intake, g & $110.33^{\mathrm{b}}$ & $115.14^{\mathrm{a}}$ & $91.52^{\mathrm{c}}$ & $89.69^{\mathrm{d}}$ & 4.51 \\
\hline Mortality \% & $10^{\mathrm{a}}$ & $10^{\mathrm{a}}$ & $10^{\mathrm{a}}$ & $10^{\mathrm{a}}$ & 0.0 \\
\hline Feed conversion ratio & $4.32^{\mathrm{a}}$ & $4.14^{\mathrm{a}}$ & $3.34^{\mathrm{b}}$ & $2.71^{\mathrm{c}}$ & 0.09 \\
\hline
\end{tabular}

a,b means with the same letter are not significant in the same row.

NS $=$ Non significant $\quad *=$ Significant $(\mathrm{P} \leq 0.05) \quad * *=$ Significant $(\mathrm{P} \leq 0.01)$

Table 2. Effect of feeding different levels of Saccharomyces cerevisiae on carcass traits at 70 days of age

\begin{tabular}{|c|c|c|c|c|c|}
\hline \multirow{2}{*}{ Item } & \multicolumn{4}{|c|}{ Treatments } & \multirow{2}{*}{ S.E. } \\
\cline { 2 - 5 } & $\mathbf{C}$ & $\mathbf{R 1}$ & $\mathbf{R 2}$ & $\mathbf{R 3}$ & \\
\hline body weight at slaughter, g & $1530.00^{\mathrm{b}}$ & $1548.66^{\mathrm{b}}$ & $1738.00^{\mathrm{a}}$ & $1761.66^{\mathrm{a}}$ & 24.60 \\
\hline Carcass \% & $54.05^{\mathrm{b}}$ & $61.32^{\mathrm{a}} \mathrm{b}$ & $58.18^{\mathrm{ab}}$ & $64.48^{\mathrm{a}}$ & 2.66 \\
\hline Dressing \% & $52.55^{\mathrm{a}}$ & $59.80^{\mathrm{a}}$ & $57.07^{\mathrm{a}}$ & $60.87^{\mathrm{a}}$ & 2.68 \\
\hline Dressed head \% & $6.27^{\mathrm{b}}$ & $5.97^{\mathrm{cb}}$ & $5.67^{\mathrm{c}}$ & $7.08^{\mathrm{a}}$ & 0.12 \\
\hline Liver weight, g & $50.00^{\mathrm{ab}}$ & $51.33^{\mathrm{ab}}$ & $56.66^{\mathrm{a}}$ & $44.00^{\mathrm{b}}$ & 2.28 \\
\hline Liver \% & $3.27^{\mathrm{a}}$ & $3.23^{\mathrm{a}}$ & $3.25^{\mathrm{a}}$ & $2.49^{\mathrm{b}}$ & 0.11 \\
\hline Heart \% & $0.45^{\mathrm{a}}$ & $0.34^{\mathrm{a}}$ & $0.46^{\mathrm{a}}$ & $0.39^{\mathrm{a}}$ & 0.07 \\
\hline Lungs \% & $0.65^{\mathrm{a}}$ & $0.63^{\mathrm{a}}$ & $0.49^{\mathrm{a}}$ & $0.56^{\mathrm{a}}$ & 0.06 \\
\hline Kidney \% & $1.05^{\mathrm{a}}$ & $0.88^{\mathrm{ab}}$ & $0.84^{\mathrm{ab}}$ & $0.56^{\mathrm{b}}$ & 0.09 \\
\hline Caecum length, cm & $44.66^{\mathrm{a}}$ & $41.66^{\mathrm{a}}$ & $46.66^{\mathrm{a}}$ & $42.33^{\mathrm{a}}$ & 2.16 \\
\hline Two shoulders \% & $13.00^{\mathrm{ab}}$ & $13.83^{\mathrm{a}}$ & $12.46^{\mathrm{b}}$ & $13.54^{\mathrm{ab}}$ & 0.32 \\
\hline Two legs \% & $19.48^{\mathrm{bc}}$ & $20.98^{\mathrm{a}}$ & $18.84^{\mathrm{c}}$ & $20.70^{\mathrm{ab}}$ & 0.43 \\
\hline Thorax \% & $4.90^{\mathrm{a}}$ & $5.38^{\mathrm{a}}$ & $4.60^{\mathrm{a}}$ & $5.18^{\mathrm{a}}$ & 0.30 \\
\hline Lion \% & $10.12^{\mathrm{a}}$ & $11.71^{\mathrm{a}}$ & $10.06^{\mathrm{a}}$ & $10.82^{\mathrm{a}}$ & 0.54 \\
\hline Totalgiblets $\%$ & $4.77^{\mathrm{a}}$ & $4.46^{\mathrm{a}}$ & $4.56^{\mathrm{a}}$ & $3.46^{\mathrm{b}}$ & 0.19 \\
\hline
\end{tabular}

a,b means with the same letter are not significant in the same row. NS $=$ Non significant

$*=$ Significant $(\mathrm{P} \leq 0.05) \quad * *=$ Significant $(\mathrm{P} \leq 0.01) 1=$ Total giblets $($ liver + hurt + kedneys $)$.

$(\mathrm{P} \leq 0.05)$ the liver, heart, lungs and kidney percentages compared with control group. Results shown that Saccharomyces cerevisiae could supplementing in rising rabbit diets but it had an improving effect in carcass characteristic comparable with control group. Agreement results were reported by Abdel-Khalek et al (2012). They showed that hot weight, carcass weight with head, net carcass, fore and lower portions and total edible meat were significantly $(\mathrm{P}<0.05)$ higher with $1.5 \%$ of probiotic EM1 in rabbit diet than in the control group.

\subsection{Economic efficiency}

Table 3 revealed that treated rabbits with saccharomyces cerevisiae boulardii in their diets had a highly significant increase in relative economic efficiency than the control group. The relative economic efficiency of control, R1, R2 and R3 were 100, 102.15, 146.77 and 186.02, respectively. Saccharomyces cerevisiae supplementation of growing rabbits resulted in clear improvement of net income and relative economic efficiency when compared 

on Productive Performance and Economic Efficiency of Growing Rabbits

Table 3. Effect of feeding different levels of Saccharomyces cerevisiae on economic efficiency at 70 days of age

\begin{tabular}{|c|c|c|c|c|c|}
\hline \multirow{2}{*}{ Item } & \multicolumn{3}{|c|}{ Treatments } & \multirow{2}{*}{ S.E. } \\
\cline { 2 - 5 } & $\mathbf{C}$ & $\mathbf{R 1}$ & $\mathbf{R 2}$ & R3 & \\
\hline Totalfeed cost (L.E.) /head & $13.61^{\mathrm{a}}$ & $11.00^{\mathrm{a}}$ & $10.86^{\mathrm{a}}$ & $10.38^{\mathrm{a}}$ & 1.71 \\
\hline Selling price (L.E.)/head & $66.74^{\mathrm{b}}$ & $70.31^{\mathrm{b}}$ & $69.98^{\mathrm{b}}$ & $79.72^{\mathrm{a}}$ & 1.65 \\
\hline Totalfeed intake kg/head & $3.24^{\mathrm{a}}$ & $2.62^{\mathrm{b}}$ & $2.46^{\mathrm{c}}$ & $2.47^{\mathrm{c}}$ & 3.40 \\
\hline Net profit (L.E.) & $46.90^{\mathrm{c}}$ & $49.45^{\mathrm{bc}}$ & $52.70^{\mathrm{b}}$ & $62.45^{\mathrm{a}}$ & 1.06 \\
\hline Net revenue (L.E.) & $27.72^{\mathrm{c}}$ & $30.11^{\mathrm{bc}}$ & $33.57^{\mathrm{b}}$ & $42.56^{\mathrm{a}}$ & 1.51 \\
\hline Economic Efficiency & $1.86^{\mathrm{c}}$ & $1.90^{\mathrm{c}}$ & $2.73^{\mathrm{b}}$ & $3.46^{\mathrm{a}}$ & 0.30 \\
\hline Relative economic efficiency\% & $100^{\mathrm{y}}$ & $102.15^{\mathrm{y}}$ & $146.77^{\prime}$ & 186.02 & \\
\hline
\end{tabular}

a,b,c means with the same letter are not significant in the same row.

$\mathrm{NS}=$ Non significant $*=$ Significant $(\mathrm{P} \leq 0.05) \quad * *=$ Significant $(\mathrm{P} \leq 0.01)$

$\mathrm{C}=\mathrm{Control}, \mathrm{R} 1=\mathrm{Basal}$ diet $+100 \mathrm{gm}$ saccharomyces, $\mathrm{R} 2=$ Basaldiet $+200 \mathrm{gm}$ saccharomyces, $\mathrm{R} 3=$

Basaldiet+400 gm saccharomyces/Ton diet.

Feed intake cost $=($ Totalfeed intake $\times \mathrm{Kg}$ feed cost $) / \mathrm{L} . \mathrm{E}$.

The Net revenue $=($ Price body weight gain - totalfeed cost $) /$ L.E.

Economic efficiency $(\mathrm{EE})=($ Net revenue $/$ totalfeed cost $) / \mathrm{L} . \mathrm{E}$.

Relative economic efficiency $(\%)=(\mathrm{EE}$ for $\mathrm{Tr} / \mathrm{EE}$ for control $) \times 100$

Price of one $\mathrm{kg}$ pellets basaldiet was $4.20 \mathrm{~L}$.E. and $\mathrm{kg}$ of marketing live weight 40 L.E. Price of

$1 \mathrm{~kg}$ of Saccharomyces cerevisiae $=350$ L.E.

with the control group. Agreement results were reported by Amber et al (2014) who found carcass percentage was significantly increased $(\mathrm{P}<0.01)$ by supplementing probiotic and prebiotics in a rabbit's diet.

\subsection{Diet cost analysis}

In our research, labor and carriage costs were not included, but the costs of supplementations were considered. Meanwhile labor and carriage costs were similar in all tested diets, the present comparisons are acceptable. Among the tested treatments, supplementation of Saccharomyces cerevisiae had the lowest cost of feed per live weight as well as dressed weight compared to non-supplemented ones. Current data revealed that supplementation of Saccharomyces cerevisiae is the best economical feeding strategies that would give extra revenue to the farmer.

\section{Conclusion}

The probiotic (Saccharomyces cerevisiae) boulardii had a positive impact on growth traits, feed efficiency and economic efficiency of rabbits when add 200 or $400 \mathrm{gm} / \mathrm{ton}$ of feed.

\section{References}

Abdel-Khalek AE, Abdelhamid AM, Mehrez AF, El-Sawy I (2012) Growth performance, digestibility coefficients, blood parameters and carcass traits of rabbits fed biologically treated diets. J Animal and Poultry Prod, Mansoura Univ, 5, 227-239.

Amber KH, Fatma M, Abd El-Nabi WA, Morsy SHA (2014) Effect of dietary supplementation of probiotic and Prebiotic on preventing post weaning digestive Disorders and productive performance of growing Rabbits. Egypt Poult Sci 34, 19-38.

AOAC (Association of Official Analytical Chemists) (1990) Official Methods of Analysis. $16^{\text {th }}$ ed. Arlington, VA.

Basavaraj M, Nagabhushana V, Prakash N, Appannavar MM, Wagmare P, Mallikarjunappa S (2011) Effect of Dietary Supplementation of Curcuma Longa on the Biochemical Profile and MeatCharacteristics of Broiler Rabbits under Summer Stress. Veterinary World 4, 15-18. 
Belhassen T, Bonai A, Gerencsér ZS, Matics ZS, Tuboly T, Bergaoui R and Kovacs M. (2016) Ef fect of diet supplementation with live yeast succharomyces cerevisiae on growth performance, caecal ecosystem and health of growth rabbits. World Rabbit Sci. 24, 191-200.

Bovera F, Lestingi A, Iannaccone F, Tateo A, Nizza A (2012a) Use of dietary mannanoligosaccharides during rabbit fattening period: Effects on growth performance, feed nutrient digestibility, carcass traits, and meat quality. $J$ Anim Sci, 90, 3858-3866.

ChukaEzema andDidacusChukwuemekaEze (2010) Determination of the effect of probiotic (Saccharomyces cerevisiae) on growth performance and hematological parameters of rabbits. Comp Clin Pathol, 10, 16-26.

De Blas, JC and Mateos, GG (1998) Feed formulation. In: De Blas J.C., Wiseman J (Ed). CABI Publishing, UK, pp 241-254.

Duncan, DB (1955). Multiple range and multiple $F$ tests.

Falcao-e-Cunha, L, Castro-Solla, L, Maertens, L, Marounek, M, Pinheiro, V, Freire, J, Mourao, JL (2007) Alternatives to antibiotic growth promoters in rabbit feeding: a review. World Rabbit Science 15, 127-140.

Kritas, SK, Petridou, EI, Fortomaris, P, Tzika E, Arsenos, G, Koptopoulos, G, (2008) Effect of inclusion of probiotic on micro-organisms content, health and performance of fattening rabbits: 1. Study in a commercial farm with intermediate health status. $9^{\text {th }}$ World Rabbit Congress, Verona, Italy, 717-721.

LI, P, Gatlin, DM (2003) Evaluation of brewers yeast (Saccharomyces cerevisiae) as a feed supplement for hybrid bass (Morone chrysops $\times$ M. Saxatilis). Aquaculture, 219, 681-692.

Maertens L, De Groote G (1992) Effect of dietary supplementation of live yeast on the zootechnical performances of does and weaning rabbits. J Appl Rabbit Res 15, 1079-1086.
Nilay, S, Galip N (2014) Effect of Saccharomyces cerevisiae and Spirulina platensis on Growth Performances and Biochemical Parameters in Rabbits. Kafkas Univ Vet Fak Derg, 3, 331-336.

ONIFADE, AA (1998) Proposing fortification of foods with yeast for optimal nutrition value and salubrious effects. Nutrition \& Food Science 4, 223-226.

Owen V (1981) Rabbit meat for developing countries. World Anim, Rev 9, 2-10.

Ozcan N (2001) Heterologous expression of genes in the yeast saccharomyces cerecisiae. Turk J Agric 4, 25-45

Saegusa, S, Totsuka, M, Kaminogawa, S, Hosoi, T (2004) Candida albicans and Sacchromyces cerevisiae induce interlukin- 8 production from intestinal epithelial-like Caco-2 cells in the presence of butyric acid. FEMS Immunology and Medical Microbiology 41, 227235.

SAS (2002) Statistical Analysis Systems. SAS Version 9.1. SAS Institute Inc, Cary.

Shaiful AAA (1992) The scope of biotechnology in livestock nutrition in the developing countries. Proceedings of an International symposium held at the institute of Basic Animal Sciences, Faculty of Agriculture and Horticulture, Humboldt-University 26-35.

Shehata AS, Tawfeek MI (2010) Probiotics as feed additives in rabbits. The $6^{\text {th }}$ Inter. Con on Rabbit Prod in Hot Clim, Assuit, Egypt 455471.

Shrivastava AK, Tiwari KK, KumarR, Jha RR (2012) Effects of feed additives on body weights at different ages in rabbit. Scholarly Journal of Agricultural Science 11, 277-282.

Toghyani M, Toghyani M, Tabeidian SA (2011) Effect of probiotic and prebiotic as antibiotic growth promoter substitutions on productive and carcass traits of broiler chicks. International Conference on Food Engineering and Biotechnology pp 82-86. 